\title{
Adult Granulosa Cell Tumor: A Small Mass Producing Troublesome Morbidity To A Woman
}

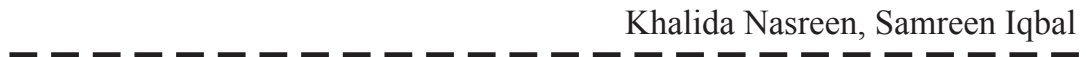

Abstract:

Granulosa cell tumors are sex-cord stromal tumor ofovary, a rare neoplasmaccounting for approximately 3-5\% of all ovarian malignancies. Hormone producing tumor, a total of $95 \%$ of all GCTs are adult type and of large size. A majority of women present with abdominal mass and diagnosis made on histopathology. While small size symptoms producing Granulosa cell tumors are rare and it's a rare virilizing tumor of adolescents. Adult Granulosa cell tumor is a clinically and molecularly unique subtype of ovarian cancer. The present case study reports on a case of a small size Granulosa cell tumor producing postmenopausal bleeding in 56-year-old woman.

Key words: Adult Granulosa cell tumors, ovarian carcinoma, FOXL2 C134W mutation

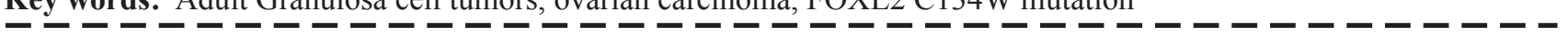

\section{INTRODUCTION:}

Granulosa cell tumors (GCTs) are sex-cord stromal tumor of ovaryaccounting for approximately $3-5 \%$ of all ovarian malignancies with a relatively favorable prognosis. A total of $95 \%$ of all GCTs are adult typeand $5 \%$ are juvenile type. Majority of patients are diagnosed in stage I due to the enlarge size and irregular vaginal bleeding ${ }^{1,2,3}$.

Granulosa cell tumorpredominantly produce estrogen and androgens and these hormones are responsible for patient's symptoms like irregular vaginal bleeding, postmenopausal bleeding and hirsiutism ${ }^{4}$. Viralization is the prominent feature of juvenile type of Granulosa cell tumors ${ }^{5}$. Adolescent girls become muscular, develop excessive and male pattern body hairs, breast atrophy, and irregular vaginal bleeding. Surgical management based on stage of tumor as well as age of the patient. Premenarchal and reproductive age women with early stage disease are often managed with unilateral salpingooophorectomy and appropriate surgical staging in an attempt to preserve fertility. In postmenopausal women and those who have completed child bearing, surgery consists of a total abdominal hysterectomy and bilateral salpingooophorectomy, along with standard surgical staging ${ }^{1}$.

\section{Case Report:}

A 56-year-old female, Nulliparous, married for 14 years, Menopausal for 10 years, presented to Gynae OPD with history of Postmenopausal bleeding on \& off for the last 2 years. There is no comorbid, on examination she is of average height and built. On examination: pulse 90b/m, BP, 130/90

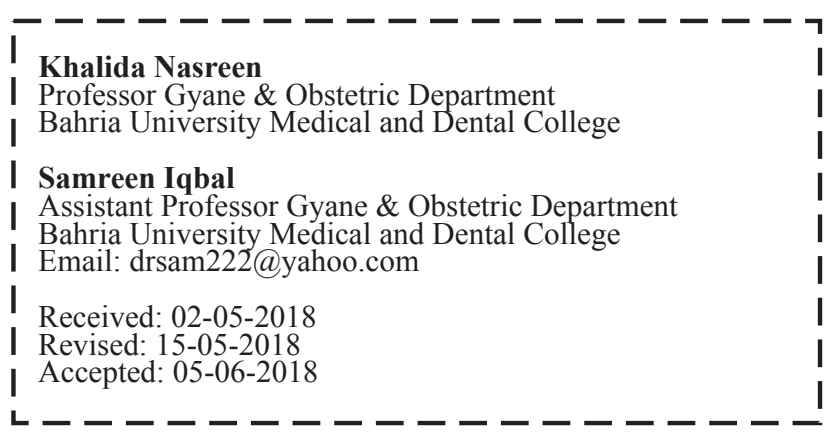

$\mathrm{mmHg}$, temperature $-98^{\circ} \mathrm{F}, \mathrm{R} / \mathrm{R} 12 \mathrm{~b} / \mathrm{m}$, Chest was clear on auscultation, on abdominal examination abdomen was flabby, No mass palpable, fluid thrill and shifting dullness was negative, gut sounds were audible. On Speculum examination cervix was swollen, nebothian cysts present. On bimanual examination: N/S uterus, Fornixes. On Laboratory investigations, Blood group $\mathrm{O}+, \mathrm{Hb} \%-13 \mathrm{~g} / \mathrm{dl}$, RBs $95 \mathrm{mg} \%$, HepBsAg - Negative, Anti HCV antibodies- Negative.

On Ultrasound uterus- $\mathrm{A} / \mathrm{V}, \mathrm{N} / \mathrm{S}$, endometrium thick $1.1 \mathrm{~cm}$, both ovaries were normal in size. One year back her endometrial sampling was done for the same complaint and histopathology report showed that focal complex hyperplasia with endometrial polyp. She has been prescribed multiple medications from many doctors but she got temporary relief. We have planned total abdominal hysterectomy and bilateral salpingo-oophorectomy for her. Work up has been completed; fitness for general anesthesia has been taken. After taking written informed consent her total abdominal hysterectomy and bilateral salpingo-oophorectomy done and sample contain uterus, both fallopian tubes and both ovaries. Patient remains stable after operation and recovery was speedy. Histopathology report showedcervix- chronic cervicitis, Endometriumdisordered proliferative with fixation artifacts, right ovary - unremarkable, left ovary- adult Granulosa cell tumor measuring $1.5 \times 1.0 \mathrm{~cm}$. On immunohistochemistry: Calretinin - positive, Inhibin- positive, Ki 67- Negative. As the whole tumor removed with surgery and there was no evidence of tumor spread beyond ovary so she is not a candidate for chemotherapy or radiotherapy.

\section{DISCUSSION:}

Granulosa cell tumors are divided into two histological subtypes, classified as adult- type and juvenile - type. The adult subtype representing $95 \%$ of all Granulosa cell tumors (GCTs), occur in perimenopausal or postmenopausal women, at a peak age frequency between 50 and 55 years ${ }^{1,2,3}$. The symptoms of the tumor occur due to its hormone production: hyperestrogenism in $97-98 \%$ of the cases, and hyperandrogenism in $2-3 \%$ of the cases. Clinical manifestations of estrogen producing tumor are amenorrhea, dysfunctional 


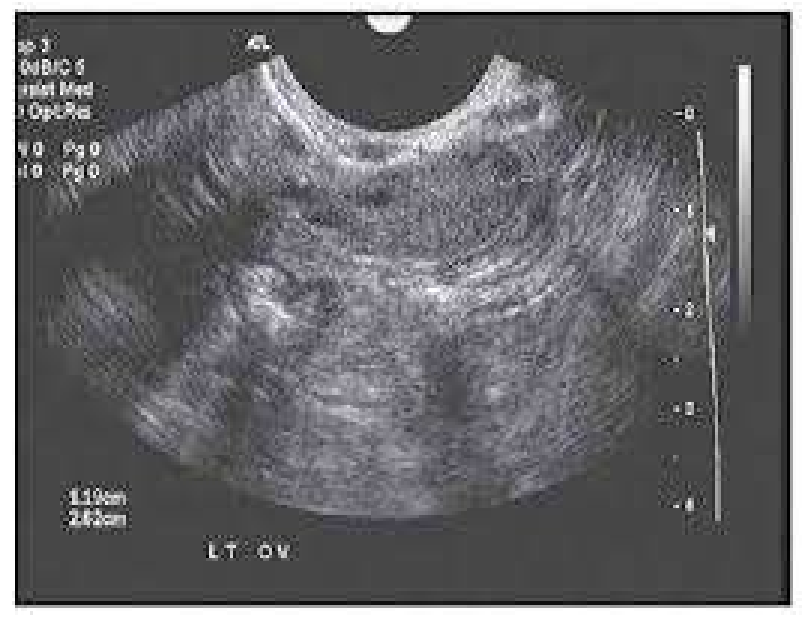

a) Normal size ovary with small cystic area measuring $1 \mathrm{X} 1 \mathrm{~cm}$.

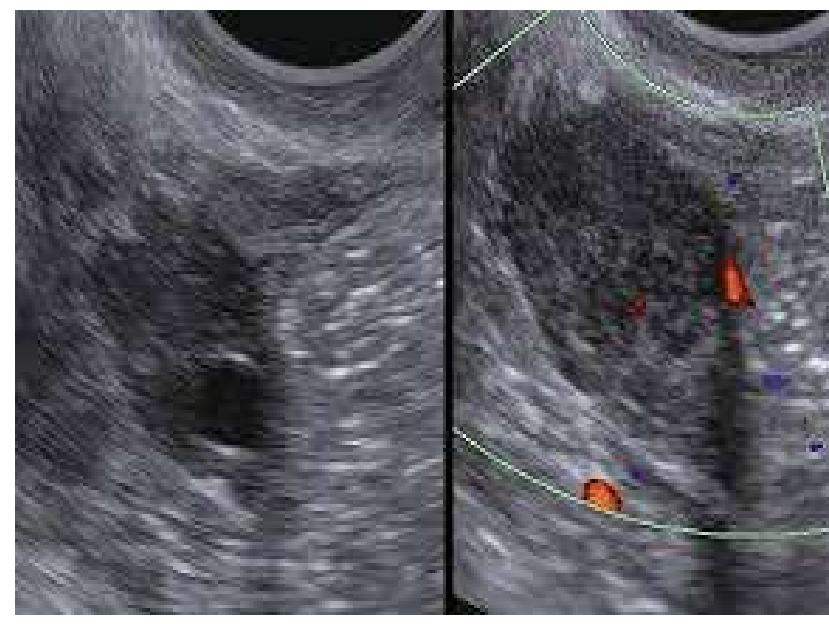

b) Doppler ultrasound of ovary showing active blood flow.

\section{CONCLUSION:}

Every patient with postmenopausal bleeding should be investigating for Adult granulosa cell tumor as a small tumor can produce a troublesome morbidity to the patient. Majority of patients with granulosa cell tumors of the ovary present in early stage. Surgery is the primary treatment modality for granulosa cell tumors. Advance stage and presence of residual disease were associated with inferior survival, but only prospective studies can ascertain their definite role.

\section{REFERENCES:}

1. Khosla D, Dimri K, Pandey AK, Mahajan R, Trehan R. Ovarian granulosa cell tumor: Clinical Features, Treatment, Outcome, and Prognostic Factors. N Am J Med Sci. 2014; 6(3): 133-138.

2. Ayhan A, Salman MC, Velipasaoglu M, Sakinci M, and Yuce K. Prognostic factors in adult granulosa cell tumors of the ovary: a retrospective analysis of 80 cases. J Gynecol Oncol. 2009; 20(3): 158-163

3. Suparna Ghosh (Ray), Kundu K, Bhadra D, Bandyopadhyay R, Das A, Mukherje J. Juvenile Granulosa Cell Tumour with Precocious Puberty. International Invention Journal of Medicine and Medical Sciences. 2014; 1(8); 95-99.

4. Adefris M, Fekadu E. Postmenopausal mild hirsutism and hyperandrogenemia due to granulosa cell tumor of the ovary: a case report. J Med Case Rep. 2017; 11: 242. DOI 10.1186/s 13256-017-1411-3.

5. Bús D, Buzogány M, Nagy G, Vajda G. Rare virilizing granulosa cell tumor in an adolescent. Mol Clin Oncol. 2017; 6(1): 88-90.

6. Jamieson S, Butzow R, Andersson N, Alexiadis M, UnkilaKallio L, Heikinheimo M, Fuller PJ, Anttonen M. The FOXL2 C134W mutation is characteristic of adult granulosa cell tumors of the ovary. Modern Pathology 2010; 23: 1477-85. doi: 10.1038/modpathol.2010.145.

7. Färkkilä A, Haltia UM, Tapper J, McConechy MK, Huntsman DG, Heikinheimo M. Pathogenesis and treatment of adulttype granulosa cell tumor of the ovary. Ann Med. 2017; 49(5): 435-447 
Adult Granulosa Cell Tumor: A Small Mass Producing Troublesome Morbidity To A Woman

8. Farinola MA, Gown AM, Judson K, Ronnett BM, Barry TS, Movahedi-Lankarani S, Vang R. Estrogen receptor alpha and progesterone receptor expression in ovarian adult granulosa cell tumors and Sertoli-leydig cell tumors.Int J Gynecol Pathol. 2007; 26(4): 375-82.

9. Isguven P, Yoruk A, Adal SE, Arslanoglu I, Ilvan S, Yildiz M. Adult Type Granulosa Cell Tumor Causing Precocious Pseudopuberty in a 6 Year-old Girl. Journal of pediatric endocrinology \& metabolism: JPEM 2003; 16(4): 571-3.
10. Färkkilä A, Unkila-Kallio L Diagnosis and follow-up observation of granulosa cell tumor of the ovary are becoming more precise. Duodecim; Laaketieteellinen Aikakauskirja. 2016; 132(11): 1033-39.

11. Seagle BL, Ann P, Butler S, Shahabi S. Ovarian granulosa cell tumor: A National Cancer Database study. Gynecol Oncol. 2017; 146(2): 285-91

12. Brigitte E. Miller M.D, Beth A. Barron M.D, Jim Y. Wan Ph.D, James E. Delmore M.D, Elvio G. Silva M.D, David M. Gershenson M.D. Prognostic factors in adult granulosa cell tumor of the ovary. American cancer society 1997; 79(10): 1951-55 